\title{
Constructing female entrepreneurship policy in the UK: is the US a relevant benchmark?
}

\author{
Susan Marlow \\ Department of Human Resource Management, De Montfort University, The Gateway, \\ Leicester LE1 9BH, England; e-mail: smhum@dmu.ac.uk
}

Sara Carter

Department of Management, University of Stirling, Stirling FK9 4LA, Scotland; e-mail: sara.carter@stir.ac.uk

\section{Eleanor Shaw}

Department of Marketing, University of Strathclyde, Glasgow G4 0BR, Scotland; e-mail: eleanor.shaw@strath.ac.uk

Received 30 March 2007; in revised form 20 October 2007

\begin{abstract}
Successive UK governments have introduced a range of policy initiatives designed to encourage more women to start new firms. Underpinning these policies has been an explicit ambition for the UK to achieve similar participation rates as those in the US where it is widely reported that women own nearly half the stock of businesses. The data underlying these objectives are critically evaluated and it is argued that the definitions and measures of female enterprise used in the UK and the US restrict meaningful comparisons between the two. It is suggested that the expansion of female entrepreneurship in the US is historically and culturally specific to that country. UK policy goals should reflect the national socioeconomic context, while drawing upon good practice examples from a range of other countries. The paper concludes by discussing the economic and social viability of encouraging more women in the UK to enter self-employment without fully recognising the intensely competitive sectors in which they are often located.
\end{abstract}

\section{Introduction}

It has been widely recognised that women are a potential reservoir of entrepreneurial talent and innovation (OECD, 2003); however, much of this talent remains unrealised as women face specific barriers associated with their gender. These barriers discourage many women from entering self-employment and constrain the growth and sustainability of women-owned firms (Marlow and Carter, 2006). Consequently, there is a notable male domination of small-business ownership and self-employment (Brush et al, 2006a; 2006b; Minitti et al, 2005). In the UK, for example, official statistics for business ownership suggest that women comprise only $12 \%-17 \%$ of all business owners (Small Business Service, 2006). Similarly, figures for self-employment reveal that, despite both the substantial growth of the UK self-employed population over the past fifteen years and the faster increase in rates of women's self-employment, the female share of self-employment has, over the same period, remained relatively stable at around 26\% (Labour Force Survey, 2005/06). Considered collectively, these figures suggest that the sustainability of female-owned businesses may be weaker than those owned by men and that higher rates of exit may account for the static nature of women's share of the UK's self-employed population.

Although the situation in the UK broadly reflects that of other Northern European countries, it is often and unfavourably compared with that of the US (Carter and Shaw, 2006; Small Business Service, 2003), where it is estimated that there are currently 10.6 million women-owned firms, accounting for $48 \%$ of all privately held firms in the US (Brush et al, 2006b; CWBR, 2004; 2005). According to official statistics, the number of women-owned businesses has expanded more rapidly in the US than in almost any 
other developed economy (Brush et al, 2006b; CWBR, 2004). Consequently, the US is often regarded as an exemplar of progress regarding the expansion of female entrepreneurship and is used as a benchmark for achievement in other economies. For example, the UK Department of Trade and Industry's strategic framework for women's enterprise notes that the objective of contemporary policy on female entrepreneurship is to

"increase significantly the numbers of women starting and growing businesses in the

UK, to proportionately match or exceed the level achieved in the USA" (Small

Business Service, 2003, page 4).

While matching or exceeding US trends of participation has become an abiding aspiration within policy initiatives aimed at expanding women's business ownership in the UK, we argue that there is a need to consider the robustness of comparative data together with the displacement and sustainability issues related to female enterprise.

A critical evaluation of this approach is developed based upon a range of arguments, and this is structured as follows. First, to establish context, a short discussion of the influence of gendered characterisation upon entrepreneurship is presented. Second, it is demonstrated that comparisons between levels of female enterprise within the UK and the US are based upon incompatible data. Longstanding difficulties in understanding and recording women's contribution to entrepreneurship together with discrepancies in defining and measuring women's business ownership may serve to exaggerate the degree of difference between the US and the UK. As such, the aim of attaining US levels of female participation in business ownership in the UK is questioned. Third, a contextual analysis of the growth of female entrepreneurship in the US is presented. This argues that women's apparently more active involvement in entrepreneurship in the US has arisen from a specific set of historical and economic circumstances. This reveals the positive impact of a sequence of socioeconomic, political, and legal influences unique to the US, including the 1960s Civil Rights movement, the introduction of affirmative action policies, and the emergence of both a powerful advocacy movement supporting the interests of women business owners and a strong tradition of liberal feminism. The influence of the liberal, market-based approach to social-welfare provision in the US is then noted, suggesting that such an approach channels greater numbers of the persistently poor, particularly lone mothers, towards self-employment in the absence of long-term income support. Finally, it is concluded that, as in the US, the historical and socioeconomic context of the UK is a fundamental determining influence on rates of female participation in enterprise, and that participation rates may prove stubbornly resistant to any policy attempts to increase them.

\section{The influence of gender on business ownership}

The extant literature pertaining to female entrepreneurship has grown considerably over the past fifteen years (Carter and Shaw, 2006). Axiomatically, this literature is embedded within the notion of gender in that it is premised upon the differentiated experiences of male and female business owners. However, such differences are frequently taken as given with no acknowledgement of the conceptual basis of gender differentiation and value characterisation. This leads to weak analytical framing and poorly founded assumptions (Marlow, 2002; Mirchandani, 1999). Accordingly, in this discussion, gender is conceptualised as a social construction of sex where characteristics that underpin notions of masculinity and femininity are ascribed to men and women (Ahl, 2002; 2006; Oakley, 1973). Gender emerges as a number of stereotypical behaviours associated with the masculine and the feminine, where the former is privileged over the latter and so supports a hierarchical valuation of traits and characteristics (Cranny-Francis et al, 2003). In turn, men and women broadly conform 
to gendered expectations; as West and Zimmerman (1987) suggest, we all 'do gender' and even those who adopt characterisations of the other sex are still, in effect, 'doing gender'. This leads to what Bem (1993) refers to as the lens of gender in that it shapes perceptions of how we, and others, should act. It has been demonstrated that, although gender as a concept is dynamic, changing over time, space, and context (Cranny-Francis et al, 2003), it is persistent in the manner in which it orders and values the masculine above the feminine. It is unquestionable that it will not intrude into the experience of self-employment.

Despite historically rooted debate regarding the influence of gender subordination upon women (Mead, 1949; Oakley, 1973; Segal, 1989), recognition of how gendered ascriptions might influence the experience of self-employment dates only from the mid-1980s. Before this, the contribution women made to the small-business sector either as firm owners in their own right or, more commonly, as providers of labour to family-owned firms, went largely unrecognised (Carter and Bennett, 2006). This 'invisibility' of women's involvement in, and contribution to, entrepreneurship is not only embedded in gendered ascriptions but rather is encouraged by deeply rooted institutional and legal frameworks which historically and currently serve to restrict the accurate and official recording, measurement, and recognition of the contribution made by women to business ownership. A particular example of this is provided by the unmeasured contribution which women make to family-owned firms. This has been recognised both by business historians and by entrepreneurship scholars. For example, the work of Colli and Rose (2003) and Colli et al (2003) provides historical evidence which challenges traditional models of family business by revealing the role of and contribution made by women to family firms in Britain, Spain, and Italy in the 19th and 20th centuries. Similarly, Hamilton's (2006) discussion of the narrative accounts of those involved in the establishment and second-generation ownership of a family firm provides contemporary evidence of both the involvement of women in family business and the continuing invisibility of this in official measures of business ownership.

Such invisibility of women in official indicators and measures of entrepreneurship and business ownership has encouraged a discourse within entrepreneurship which assumes that the self-employed are male (Ahl, 2006; Ogbor, 2000). As Holmquist and Sundin (1989) observe, "entrepreneurial theories are made by men, for men and about men" (page 1). As such, the idealised entrepreneur embodies masculine characteristics and behaviours such as assertiveness, aggressiveness, competitiveness, and propensity for risk (Ahl, 2006). Collins and Moore (1964) summarise the stereotypical perception of entrepreneurs as "essentially more masculine than feminine, more heroic than cowardly" (page 5). Contemporary analyses of the entrepreneurial discourse confirm that the male norm and the 'heroic myth' still underpin underlying assumptions regarding the essence of entrepreneurship (Ahl, 2006; Hamilton, 2006; Ogbor, 2000). Consequently, the prevailing, androcentric, view of the small-firm owner suggests that the norm is a man who has command of the behaviours and resources associated with masculinity that effectively marginalise women, representing them as 'other' (de Beauvoir, 1972; Shakeshaft and Nowell, 1984).

Although a convincing body of evidence regarding female subordination already existed within the broader social sciences, the view that gender would influence women's experiences of business ownership was rarely considered until the mid-1980s (see, as exceptions, Schreier, 1973; Schwartz, 1976). Contemporary evidence has now revealed that not only are women less likely to become self-employed, their experience of business ownership differs markedly from that of men (Ahl, 2002; 2006; Carter et al, 2001; Marlow, 1997; Mirchandani, 1999; 2005). Within developed nations, most female self-employment is confined to traditionally feminised occupational sectors within the 
service sectors (Carter and Shaw, 2006), reflecting the disadvantageous occupational segregation evident in waged labour (Hakim, 1979; 1989). In the same way that such segregation in employment constrains income and opportunity for women, so it limits profit and growth in self-employment (Marlow, 2002). Consequently, women-owned firms are found to consistently underperform on a range of substantive measures in comparison with those of their male counterparts (Rosa et al, 1996; Watson and Robinson, 2003). The causes of female underperformance are rooted in the characteristics of women-owned businesses. Women entering self-employment are more likely to be younger than men, and their businesses are more likely to be newer, located within the home, and operated on a part-time basis (Carter and Shaw, 2006; Small Business Service, 2003). ${ }^{(1)}$ Women's enterprise reflects these characteristics, as self-employment is more likely to be utilised as a flexible response to the need to combine waged and domestic labour - a response that is rare among men (Baines et al, 2003; Rouse and Kitching, 2006).

Operating businesses on a flexible and fragmented basis is known to reduce their legitimacy (Belle and La Valle, 2003; Rouse, 2005; Rouse and Kitching, 2006), in the same way as employment status is devalued when undertaken on a part-time basis as it suggests a lesser commitment to waged work (Charles, 2003). Moreover, a fundamental characteristic of economic activity is its separation from the domestic sphere (Bradley et al, 2000). Accordingly, the credibility of female entrepreneurship is undermined by its association with, and reflection of, gendered norms in the socioeconomic context. However, gender is a dynamic, not determining, influence and it is axiomatic that there will not be homogeneous patterns of disadvantage.

Thus, the increasing rates of participation in business ownership and the growing penetration of women into traditional areas of male entrepreneurship in the US are held as an example of change and achievement despite gender disadvantage (Brush et al, 2006b). Indeed, it is clear that female entrepreneurs in the US have made considerable progress in increasing their share of business ownership (Brush and Hisrich, 1999; CWBR, 2004). Nevertheless, for this example to be the benchmark for other developed economies upon which policy initiatives might be based, careful scrutiny should be afforded to how entrepreneurial activity is measured in order to assess the veracity of contemporary comparisons. Further, the specific socioeconomic changes in the US during the 1960s and 1970s that established the foundation for the initial expansion of female entrepreneurship require critical evaluation in order to understand the context of growth in female business ownership in the US.

\section{Defining and measuring enterprise}

Defining and measuring women's enterprise have always been and continue to be problematic for researchers and policy makers seeking to enumerate a nation's business stock (Carter, 1993; Prowess Profile 2004; Wilson et al, 2004). These difficulties stem from two sources. First, as reported above, in the UK, women's involvement in business ownership is often marginalised to such an extent as to render their actions invisible. Both historically and currently, official records have disguised the contribution made by women to entrepreneurship in the UK. Secondly, as international comparisons of women's enterprise activity are often based on different, nationally favoured, definitions and measures, the validity of cross-country comparisons of women's involvement

(1) Notably, given the same starting resources in the form of financial and nonfinancial capital, women-owned businesses perform equally well as male-owned businesses. While there has been little recent research directly considering the performance and sustainability of female-owned firms, that which has been undertaken provides unequivocal evidence that female-owned enterprises do not lack the competence to run successful enterprises, they simply lack the resources (Rosa et al, 1996; Watson and Robinson, 2003). 
in business ownership is questionable (Crompton and Lyonette, 2006; O'Reilly, 2006). For example, in the UK, researchers have defined a woman-owned business as one that is either wholly or majority owned by one or more women. While it is widely appreciated that most enterprises depend to some extent on female participation either as owner, partner, or provider of labour to a family-owned enterprise, the benefit of defining women-owned businesses as those that are majority female-owned and managed is that researchers can more easily distinguish them from the mass of businesses that are merely reliant on women's subordinate participation. The disadvantage, however, is that-defined in this way-statistics may underestimate the contribution made by women to business ownership in the UK. The US Census Bureau (2002) similarly defines women-owned businesses as "firms in which women own $51 \%$ or more of the interest or stock of the business" (page 226). Perhaps because this narrowly drawn definition excludes the broader contribution of women to enterprise, the leading US research and advocacy organization, the Centre for Women's Business Research (CWBR), differentiates women-led businesses (those that are wholly or majority female owned) from women-owned businesses, their definition of which includes wholly and majority female-owned firms as well as those that are co-owned equally by men and women - often matrimonial partnership enterprises.

Measures of enterprise also differ at the national level. As neither of the main UK small business datasets, nor the VAT register, nor the Inter-Departmental Business Register, is gender disaggregated, UK researchers rely on the Labour Force Survey for gender-disaggregated self-employment data together with a range of smaller sample surveys of business ownership such as the "Annual Survey of Small Businesses: UK 2005" (Small Business Service, 2006). In contrast, the main US data sources of women's enterprise include the five-yearly Census of Business Owners (last conducted in 2002) and independent survey data gathered by the CWBR. Importantly, unlike the UK, few US entrepreneurship researchers use self-employment data. This difference in measurement has important implications when comparing the figures used in UK and US enterprise research. While self-employment data are often used as a proxy measure for business ownership within the UK, it is widely appreciated that self-employment does not fully account for all enterprise-related activities. Not all business owners are self-employed, and not all self-employed are regarded as business owners. Nevertheless, self-employment data have four important advantages in women's enterprise research. First, self-employment data are gender disaggregated. Second, historical data are available that demonstrate broad trends over time. Third, the data are available on a quarterly basis that highlights short-term changes, although greater reliability comes from the annual four-quarter average. Finally, and most importantly, genderdisaggregated self-employment data are comparable at the international level. In contrast, measures of business ownership vary at the national level in terms of the broad legal definitions of enterprises, the specific definitions of female ownership, and the frequency of measurement. Despite the obvious advantages, US self-employment data have rarely been used in international comparative analysis of enterprise activity either as a main measure or to supplement less easily comparable business-ownership data.

UK self-employment and business-ownership data demonstrate the relatively low levels of women in enterprise. Currently, $7.6 \%$ of all British women in employment are in self-employment, compared with $17.4 \%$ of all men (Labour Force Survey, 2005/06). Historical analysis of the Labour Force Survey reveals that, while there has been a substantial growth in the overall self-employed population, the female share has remained stable over the past fifteen years (Labour Force Survey, 1992; 2005/06; Lindsay and Macaulay, 2004). Since 1992 the number of self-employed women has increased by $12.6 \%$, a faster growth rate than that of male self-employment, while the 
female share of self-employment (26\% in 1992 and $26.6 \%$ in 2006) has hardly changed.(2) The female share of business ownership in the UK is more difficult to calculate and data are drawn from small-scale sample surveys of business owners, not specifically designed to measure women's enterprise. The "Annual Survey of Small Businesses: UK 2005" (Small Business Service, 2006), for example, suggests that "wholly femaleled' businesses account for $10 \%$ of businesses with employees and $16 \%$ of all businesses, while 'majority female-led' businesses account for $2 \%$ of businesses with employees and $1 \%$ of all businesses. Male and female equally co-owned businesses account for a further $29 \%$ of businesses with employees and $18 \%$ of all businesses.

US business-ownership data reveal that women's participation as business owners has increased significantly over the last forty years and that the trend is towards increasing participation and growing sectoral diversity (Brush and Hisrich, 1999; Brush et al, 2006b). Recent surveys suggest that there are currently 10.6 million women-owned enterprises operating in the US economy, comprising $48 \%$ of all private sector businesses (CWBR, 2004). Estimates suggest that the contribution of women-owned firms is equally impressive: women-owned firms employ 19.1 million people and generate US\$2.5 trillion in sales revenues (CWBR, 2004). When these figures are superficially compared with business-ownership rates in the UK, the crude differences are startling; however, the manner in which women's business ownership is defined and the use of enterprise data in the US and the UK differs so markedly that the utility of the comparison is questionable.

A more meaningful comparison of business-ownership levels in the UK and the US comes from carefully matching data produced using the same definitions of women's business ownership (table 1). However, even this approach is far from reliable given the differences in data sources and frequency of data collection between the main UK and US surveys. Identifying women-owned businesses as those that are either wholly or majority owned by one or more women, the definition commonly used in the UK, removes $37 \%$ of the total US 'women-owned' enterprises that are equally co-owned by

Table 1. UK and US business-ownership and self-employment measures by sex.

Measures of enterprise

Wholly or majority male led (\%)

Wholly or majority female led $(\%)$

At least $50 \%$ female owned ( $\%)$

Total privately owned wholly or majority femaleowned enterprise (millions)

Total privately owned equally (male and female) co-owned enterprises (millions)

Female self-employment rate $(\%)^{\mathrm{b}}$

Male self-employment rate $(\%)^{\mathrm{b}}$

Female self-employment share $(\%)$

Male self-employment share (\%)

UK US

$\begin{array}{lc}65.3^{\mathrm{a}} & 52^{\mathrm{d}} \\ 16.5^{\mathrm{a}} & 28^{\mathrm{d}} \\ 34.1^{\mathrm{a}} & 48^{\mathrm{d}} \\ \text { no estimates } & 6.5^{\mathrm{d}} \\ & \\ \text { no estimates } & 10.6^{\mathrm{d}} \\ & \\ 7.8 & 6.1 \\ 16.6 & 8.8^{\mathrm{a}} \\ 26.6^{\mathrm{c}} & 39.6^{\mathrm{e}} \\ 73.4^{\mathrm{c}} & 60.4^{\mathrm{e}}\end{array}$

Sources: a Small Business Service (2006) (includes those with and without employees);

b OECD (2005);

c Labour Force Survey (2005/6);

d CWBR (2005);

e US Bureau of Labor Statistics (2005).

(2) The last major shift in the female share of self-employment was in 1984, when the female share of self-employment increased from $18 \%$ to $24 \%$, a consequence of the large-scale expansion of women into the labour force and resulting adjustments to the Labour Force Survey sample base (Brooksbank, 2000). 
men and women. Wholly or majority women-owned businesses in the US comprise 6.5 million firms, $28 \%$ of all businesses, and collectively employ 9.8 million people and generate US\$1.2 trillion in sales (Brush et al, 2006b; CWBR, 2005; NWBC, 2004). ${ }^{(3)}$ A comparison of these data with the UK equivalent suggests that women-owned businesses in the US still account for a larger share of total businesses than is the case in the UK (28\% versus 17\%); however, the like-for-like comparison is much closer than the widely reported $48 \%$ versus $12 \%-17 \%$ female share of US and UK businesses.

The most accurate UK and US comparisons are drawn from self-employment data. These data are rarely used in women's enterprise policy, but reveal a radically different view of comparative UK and US enterprise rates. The US Bureau of Labor Statistics (2005) reports that the total self-employed population in the US in 2002 comprised $6.4 \%$ of total employment. Of this, male self-employment accounted for $7.3 \%$ of total male employment and female self-employment accounted for $5.4 \%$ of total female employment. The historical trend shows that the female share of US self-employment has increased modestly but consistently over the past thirty years, from $26.8 \%$ in 1976 to $39.6 \%$ in 2005 (US Bureau of Labor Statistics, 2005). Despite their increasing share, female self-employment rates are persistently low. Table 2 compares self-employment rates for men and women in the US and UK between 1990 and 2003 as reported by the OECD (2005). ${ }^{(4)}$ It demonstrates that the total self-employment rate in the UK $(12.7 \%)$ is much higher than in the US (7.6\%). The margin between rates of male self-employment in the UK $(16.6 \%)$ and the US $(8.8 \%)$ is also wide. Female self-employment rates are higher in the UK $(7.8 \%)$ than in the US $(6.1 \%)$, but the difference in female selfemployment rates between the two countries is much narrower than for both male and total self-employment rates.

Comparative analysis of UK and US self-employment data highlights an apparent anomaly within the relative rates and share of female self-employment. In the UK it is apparent that there is a relatively high rate of female self-employment $(7.8 \%)$,

Table 2. UK and US self-employment rates 1990-2003 (source: OECD, 2005, pages 105-107).

\begin{tabular}{lllllll}
\hline Year & $\begin{array}{l}\text { UK } \\
\text { total }\end{array}$ & $\begin{array}{l}\text { US } \\
\text { total }\end{array}$ & $\begin{array}{c}\text { UK } \\
\text { men }\end{array}$ & $\begin{array}{l}\text { US } \\
\text { men }\end{array}$ & $\begin{array}{l}\text { UK } \\
\text { women }\end{array}$ & $\begin{array}{l}\text { US } \\
\text { women }\end{array}$ \\
\hline 1990 & 15.1 & 8.8 & 19.9 & 10.5 & 8.9 & 6.7 \\
1991 & 14.7 & 9.0 & 19.4 & 10.8 & 8.7 & 6.8 \\
1992 & 14.8 & 8.7 & 19.3 & 10.6 & 9.1 & 6.4 \\
1993 & 14.6 & 8.8 & 19.2 & 10.9 & 9.0 & 6.4 \\
1994 & 14.8 & 8.8 & 19.6 & 10.3 & 9.0 & 7.1 \\
1995 & 14.6 & 8.5 & 19.4 & 9.9 & 8.7 & 6.9 \\
1996 & 14.0 & 8.4 & 18.6 & 9.8 & 8.5 & 6.9 \\
1997 & 13.8 & 8.2 & 18.1 & 9.5 & 8.6 & 6.7 \\
1998 & 13.2 & 7.9 & 17.2 & 9.2 & 8.3 & 6.4 \\
1999 & 12.7 & 7.7 & 16.8 & 8.9 & 7.7 & 6.2 \\
2000 & 12.3 & 7.4 & 15.9 & 8.6 & 7.8 & 6.1 \\
2001 & 12.2 & 7.4 & 16.1 & 8.5 & 7.4 & 6.1 \\
2002 & 12.1 & 7.2 & 16.1 & 8.4 & 7.4 & 5.9 \\
2003 & 12.7 & 7.6 & 16.6 & 8.8 & 7.8 & 6.1 \\
\hline
\end{tabular}

(3) Data on the economic contribution of women-owned enterprises in the UK are not collected.

(4) The self-employment data reported by the OECD show slight differences to those reported by the UK and US national datasets (the UK Labour Force Survey and the US Bureau of Labor Statistics), although the actual numbers and the overall trends are very close to those reported in time-series data from the original sources. However, in comparative analyses, data produced by supranational agencies, such as the OECD, may be more reliable sources. 
but that women comprise a relatively low share of the total self-employed population $(26.8 \%)$. In the US, the opposite occurs: rates of female self-employment are relatively low $(6.1 \%)$, but women comprise a much higher and consistently increasing share of total self-employment $(39.6 \%)$.

The reasons for the unusually high share of self-employment among US women are unclear; however, a possible explanation can be found in the connections between an individual's wealth and resource-endowment and business-entry approaches that are used within the US. While individuals with a higher resource capacity in the form of financial, social, and human capital start up in business or move from self-employment to business incorporation often for tax purposes (Hipple, 2004), those lacking these tangible and intangible resources may use self-employment as a lower-cost marketentry strategy and may remain self-employed for the duration. While there is little direct evidence of this, it is notable that estimates of earnings report that average earnings are lower among the self-employed than among the employed population, though the distribution is wider (Parker, 2004). As a relatively poorer population, more often lacking the resources necessary to invest in business ownership, women may be more likely than men to enter self-employment. It is notable also that, in the US, the greatest flows into self-employment occur during recessionary periods while the greatest flows out of self-employment occur during economic expansions (Hipple, 2004). This too suggests that self-employment may accommodate the weakest economic activities among the poorest population groups, while business incorporation indicates a growth-oriented focus among relatively resource-rich business owners. The data shown in table 2 provide partial support for this explanation. While total self-employment rates in the US have declined - largely because of the shift towards business incorporations, whose owners are subsequently classified as wage or salary workers - the rate of female selfemployment has declined less rapidly than the rate of male self-employment. Over time, this has resulted in the incremental growth in the female self-employment share as women increasingly constitute a residual pool of the self-employed (Carter and Shaw, 2006).

The following sections explore the historical circumstances that have given rise to the growth of women's economic activity within the US, and the specific characteristics of US social-welfare provision that has channeled greater numbers of the persistently poor, particularly lone mothers, towards self-employment.

\section{The socioeconomic context of female entrepreneurship in the US}

The US possesses a significantly more dynamic history of intervention, advocacy, and support for female entrepreneurship from individual business owners, pressure groups, and politicians than has been evident in the UK. To some extent, this reflects a broader interest in the contribution of smaller firms. The role and importance of small enterprises to economic development, efficiency, and employment generation in the US have been recognised for over fifty years (Acs, 1999; Audretsch, 1999). Reflecting positive support for the sector, the federal government established the US Small Business Administration (SBA) in 1953. Since then, private and public advocacy regarding the interests of small-business owners have become part of the economic fabric of the US (SBA, 2006). This can be contrasted to the UK, where smaller enterprises were relegated to niches or considered to be a dwindling remnant of a past era well into the 1980s (Scase, 1995; 2000). Consequently, the small enterprise has commanded a different space regarding importance and interest in the economic development of the US and the UK. Yet, affording a higher profile to entrepreneurial behaviour in smaller enterprises is not sufficient in itself to prompt greater female participation. Rather, it has arisen from a greater sensitivity to the importance of smaller enterprises as 
economic contributors accompanied by a growing awareness of gender inequality, discrimination, and exclusion from critical areas of socioeconomic participation in the wider context of the Civil Rights movement.

The Civil Rights movement of the early 1960s acted as a platform to draw attention to a disparate range of inequalities in North American society. As part of this debate, demands for increasing female emancipation were articulated. Given the higher profile of self-employment and business ownership within the economy, this too was incorporated into the agenda of access. The Civil Rights Act (US House of Representatives, 1964) made discrimination on the basis of race, colour, religion, sex, or disability unlawful. Building upon the impetus of the Civil Rights Act, women business owners also benefited from a series of federal acts laid down in the late 1960s and 1970s that established equal rights for women to access credit, vital to the successful start up of new ventures. Since the 1960s a range of dedicated federal legislation asserting and protecting the rights of female entrepreneurs has been a fillip to the expansion of women-owned firms.

A substantial contribution to the growth of women's business ownership in the US arose from affirmative action policies pursued during the 1970s and 1980s. Such programmes aimed to address long-term and deep-rooted discrimination against specific disadvantaged groups, such as women and minorities. It was believed that providing such positive rights offered a degree of restoration and assisted the attainment of a more just and equitable society (Skrentny, 2001). For small businesses owned by members of such groups, programmes were introduced to access direct loans or loan guarantees and preferential public and private contract procurement opportunities. While affirmative action has since been abandoned, quotas for procurement diversity, including women-owned businesses, still exist as a contemporary feature of federal and private sector contracting in the US (Boston, 1996). Such policies have shaped the ownership structure of US small businesses where women, as members of a 'special assistance' group have been deliberately included as firm owners so that organisations might benefit from positive discrimination policies (Jacobsen, 1998). Whilst this is challenging to demonstrate equivocally given the lack of comprehensive and coherent data, Rai (2003) draws upon a range of sources to suggest that such procurement policies have been influential in shaping the ownership structure of US firms not only for women, but also for minority groups. Indeed, until 1997, women only had to constitute $50 \%$ (changed to $51 \%$ after 1997) of a firm's ownership team in order for the firm to benefit from female-focused affirmative action policies.

Consequently, growing sensitivity to discrimination and inequality in the US combined with recognition of the contribution of small firms served to open new opportunities for women entrepreneurs. A broad definition of, and a strategic approach to, ownership structures combined with the interaction of a set of socioeconomic circumstances unique to the US encouraged and enabled the entry of women into business ownership. The subsequent expansion of women-owned businesses served to elevate their visibility and importance within the economy.

Such shifts in access to opportunity might be analysed in terms of a legal challenge to discriminatory behaviour combined with the market advantages of incorporating women into business ownership. This, in itself, provided a strong boost to female entrepreneurship and, in addition, the US witnessed the emergence of a powerful advocacy movement in the 1970s which has grown in strength to protect and develop the space for women's business ownership. As an example of this, the National Association of Women Business Owners, formed in 1975, successfully lobbied for a census of women business owners to demonstrate their importance to the economy, an action that has been undertaken at five-year intervals since 1977. Following recommendations from 
the President's Interagency Task Force on Women's Business Ownership, the Office of Women's Business Ownership was established within the SBA in 1978. A testament to the power and effectiveness of such advocacy groups was the enactment of a Women's Business Ownership Act (US House of Representatives, 1988). This legislation established clear priorities concerning access to credit and training, and instigated a National Women's Business Council to act as a source of advice and policy development to the President, Congress, and the SBA on issues specifically relating to women business owners. Since the 1990s the role of such advocacy and lobby groups has become further embedded and their effectiveness has been demonstrated. Across the US there is a well-established network of pressure groups that exist to protect and expand the rights of all women entrepreneurs while also promoting research, training, funding, and support. This movement has also demonstrated a growing strategic focus through the development of women's economic summits on a national and an international scale to promote networks and to exchange information and best-practice policy. This brief overview of the advocacy movement that supports female entrepreneurs in the US illustrates how a well-coordinated network of interest groups has developed over thirty years as a powerful voice in US policy formation. As such, it has consistently promoted the interests of women business owners ensuring they have maintained a high degree of visibility within the political arena.

Support for a dynamic small-firm sector in the US in the late 1950s and 1960s coincided not only with the Civil Rights movement but also with a second wave of feminist action, such that access to business ownership was part of the wider debate surrounding equality. Orloff (2003) argues that the demand for women's economic participation was facilitated in the US as the

"political context has been quite encouraging to liberal feminist civil rights in terms

of the established political discourse ... successes achieved by the women's movement

have come largely through 'sophisticated interest' groups" (page 39).

This preference for action through privatised pressure groups is also seen to be more effective in the context of the fragmented and decentralised nature of the US political system that mitigates against the development of broader social movements.

The history of support for women's business ownership in the US embodies critical elements of a liberal feminist stance shaped by the specific context of socioeconomic change in the 1960s. Breaking down barriers to traditional areas of male domination through the creation of equal rights is a fundamental notion within liberal feminism; women are able to compete upon male terms within the market, facilitating economic emancipation and leading, in turn, to social and political rights as a citizen (Lister, 2003). From this perspective the most appropriate way to establish equal rights is through legislation that signals a political will to change existing behaviour and that attaches penalties to discriminatory actions. Hence, the circumstances that facilitated the initial expansion of women's business ownership in the US were context specific. Importantly, the momentum of support has continued over time given the powerful influence of the advocacy groups monitoring and advising on policy initiatives supporting female entrepreneurship. It might be suggested that the similarities between the US and the UK context, in that both economies have equal opportunities legislation, growing female participation in waged work, and advocacy groups to support female entrepreneurship, ensure convergence. However, there are notable distinctions, particularly in the time-lagged nature of change. Whilst the UK economy is certainly more regulated in terms of employment protection, changes to open the field of self-employment began much earlier in the US economy. Moreover, much greater attention has been afforded to the issue of female entrepreneurship and business ownership such that advocacy groups have a substantially stronger voice and influence within the US. 
The image of this expansion is relatively positive and benign as it suggests women successfully gained access to a male-dominated sphere of activity through the achievement of positive rights. This has enabled women in the US to compete on male terms and to adapt to male norms of behaviour and values, so full-time employment dominates with little recognition given to women's gendered caring responsibilities (Thomas, 1997). Indeed, US government-funded support for childcare is minimal and there is little regulatory obligation upon employers to offer mandatory maternity or parental leave (Daly and Rake, 2003). Yet, reflecting the general gendered norm, US women take greatest responsibility for the provision of domestic and caring labour in the home. This creates tension for women regarding economic participation and their domestic obligations. To solve this dilemma, families purchase their welfare needs through the market with the extent and quality of provision determined by level of income (Orloff, 2003). As will now be argued, the prevalence of a liberal social-welfare model, which creates a market for care and obliges even the poorest and most vulnerable members of society to seek work, also has implications for women's participation in self-employment.

\section{Social-welfare provision in the US}

A liberal approach to social welfare is evident within the US, the UK, Australia, and Ireland (Epsing-Anderson, 1999). The onus is on the individual to make personal provision, with a clear focus on waged work as a solution to economic needs and social problems. While these nations may share this stance, the nature and extent of reliance on the market to address social welfare problems differ, with the US adopting the most individualised approach (Orloff, 2003). Daly and Rake (2003) argue that the US has a very 'small welfare state' and, in comparative terms, the poorest level of state redistribution through taxes and transfers of all developed economies. Accordingly, welfare provision is largely privatised and purchased from the market. The degree to which this responsibility disadvantages women largely depends on the family's access to resources to purchase care for dependents. Within the US there is a large low-paid sector, segregated from wealthier groups along lines of class, race, and gender (O'Connor et al, 1999), which provides low-cost services to the more affluent. Women, particularly ethnic-minority women, are overrepresented amongst low-paid care workers (Caizza et al, 2004). Consequently, while the US has a high rate of female participation in waged work and notable independent affluence among middle-class women, the liberal approach penalises women who are constrained in their access and opportunity to accumulate resources through waged work.

Lone mothers provide an illustrative example of the links between welfare regimes, poverty, and self-employment. While these women are more likely to be overrepresented amongst the persistently poor in most developed economies, the US welfare regime attaches a considerable socioeconomic penalty to lone motherhood (IWPR, 2003; Marlow et al, 2003). Approximately $25 \%$ of families in the US are headed by lone mothers, compared with 7\% headed by lone fathers (Boushey et al, 2001; IWPR, 2003). Various degrees of protection are afforded to lone mothers within many advanced economies-for example, in the Scandinavian countries motherhood is a protected status with value attached to the caring role; in effect, the state protects against the loss or absence of a wage earner in the family. This is not the case in the US where caring is marginalised from the economic order. To illustrate the impact of differing perspectives, Orloff (2003), using OECD data, found that $63 \%$ of lone mothers in the US had disposable incomes of below half the median income, compared with $6 \%$ of those in Sweden.

As some of the most disadvantaged members of society, lone mothers in the US are not protected against poverty by state welfare provision. In the 1990s welfare entitlement was changed and the Personal Responsibility and Work Opportunity Reconciliation Act 
(US House of Representatives, 1996) made it possible for individual states to restrict welfare provision to a five-year period. This has had a particularly detrimental impact upon vulnerable sectors of society, with Wolfe (2006) noting that "most of the women who left welfare remain in low paying, unskilled jobs" (page 3). There has also been some debate concerning the imposition of compulsory fertility control and the total withdrawal of benefits if a woman had another child while in receipt of welfare income (Thomas, 1997). Consequently, there is a considerable stigma attached to welfare dependency and, in effect, compulsion to move away from state income provision. As Daly and Rake argue, "lone parents fare poorly ... limited amounts of part time work and a long hours culture render this country quite inflexible" (2003, page 150). In this context, it can be argued that self-employment might be an attractive option to such disadvantaged women as it has few barriers to entry and offers both temporal and spatial flexibility in terms of operating hours and location.

To this end, women's business centres (WBCs) have recognised the importance of self-employment as an income generator for those termed 'disadvantaged women', the majority of whom are welfare-dependent with caring responsibilities and are associated with other problems such as drug abuse or have a criminal record (Jurik, 2005; Wolfe, 2006). WBCs offer a range of services to all self-employed women, but they can claim specific federal funding to organise programmes that train and support such disadvantaged women to begin new enterprises. These programmes are substantially oversubscribed, even though there is a notable degree of compulsion to complete the training and to commence trading. A high level of default has implications for federal funding, so little leeway is awarded to those who experience difficulties with the programmes (Prowess Profile 2006). WBCs' client evaluations revealed that half of the women who were sampled reported that business ownership had not led to any beneficial economic impact upon their circumstances (CWBR, 2004; Wilson et al, 2004). Furthermore, Jurik (2005) found that the majority of businesses founded by former welfare recipients were fragile with poor prospects for income generation and/or survival. She argues that,

"to imagine that a brief training course and small business loan will result in a viable pathway to economic success is wishful thinking at best. ... these programs serve neither the poor nor most needy" (page 134).

Consequently, the complex combination of the Civil Rights movement, affirmative action policies and powerful advocacy, and feminist movements concentrating on enabling women to access the normative economic sphere together with a liberal approach to social-welfare provision have supported US women's growing independence, but largely as 'honorary' men (Marlow, 2002). This model has a two-pronged impact on business ownership. On the one hand, it enables women to challenge masculine domination of the entrepreneurship field, hence the expansion of business ownership and greater sectoral diversity. On the other hand, easy access to self-employment for the unskilled and inexperienced, elements of temporal and spatial flexibility, combined with an imperative for economic activity make it attractive to disadvantaged women particularly in the absence of social-welfare provision.

\section{Conclusion}

Recognising the economic and social benefits of encouraging more women into business ownership, contemporary UK policy aspirations in this area are underpinned by the objective of meeting or exceeding US levels of female participation in entrepreneurship where women-owned firms are reported to account for $48 \%$ of all privately owned business (Brush et al, 2006b; CWBR, 2004; 2005). In the UK, such objectives are appealing as the female share of self-employment has remained constant at around 
$26 \%$ over the past twenty years (Labour Force Survey, 2005/06). However, significant disparities in definitions and measurement of female enterprise between the UK and the US, combined with an analysis of the unique socioeconomic history and current context for female entrepreneurship in the US, suggest that current UK targets for increasing female participation in business ownership may be neither achievable nor sustainable.

Defining and measuring women's enterprise have been consistently problematic for researchers and policy makers alike. Compounding this challenge are deeply rooted institutional and legal frameworks which, in the UK, have served to marginalise and make invisible women's contribution to entrepreneurship and to prevent accurate recording of the contribution that women make to enterprise. When seeking to draw international comparisons, this challenge is heightened by the various nationally favoured definitions and measures used to map the size and scale of women's enterprise. Particular to UK - US comparisons, the analysis presented suggests that data routinely used to calculate levels of female entrepreneurship in each economy are incompatible. This measurement discrepancy is rarely recognised and discussed. Yet, importantly, the definition typically used to measure levels of female entrepreneurship in the US exaggerates the extent of the disparity. Although rarely quoted in women's enterprise policy, when self-employment data are used for UK - US comparisons of female participation in entrepreneurship, a different, if somewhat complex, picture emerges. Those data reveal that, while the female share of the total self-employed population is higher in the US $(39.6 \%)$ than in the UK $(26 \%)$, the female self-employment rate is actually higher in the UK (7.8\%) than in the USA $(6.1 \%)$ (Carter and Shaw, 2006). As discussed, a number of alternative explanations can be identified to account for these figures. Significant within these is the suggestion that the UK female share of self-employment has, for over fifteen years, remained static at around $26 \%$ because the higher female self-employment rate is matched by a similar rate of females exiting self-employment. The fragile nature of UK self-employed women indicated by these figures has implications for the economic and social viability of policy designed to boost the female share of self-employment to meet US levels.

Importantly, these figures suggest that differences in levels of female participation in business ownership require an analytical framework that moves beyond statistical comparisons. Critical evaluation of the unique socioeconomic history and context for female entrepreneurship together with consideration of the liberal approach to welfare provision favoured in the US provide greater insight into why the female share of business ownership is greater in the US. These analyses suggest it may be difficult to replicate US levels of female participation in the UK given a markedly different socioeconomic history. The current US climate of support and advocacy for female enterprise emerged from a specific and unique set of historical and economic circumstances. A notable legacy of the Civil Rights and liberal feminist movements of the 1950s and 1960s was the challenge to labour-market discrimination which enabled more women to acquire the resources necessary for business ownership. Combined with affirmative action policies of the 1970s and 1980s and the emergence of a powerful advocacy movement, the interplay of this unique set of socioeconomic factors served to encourage greater penetration of women into waged work, including business ownership and self-employment and to advocate for their fair and equal treatment. Analysis suggests that, in addition to differing historical circumstances, differences in welfare regimes have implications for female participation in business ownership. In the US the liberal market-based approach to welfare provision has significant implications both for the most disadvantaged members of society and for levels of female entrepreneurship. With minimal and time-constrained state welfare support, but with an open labour economy, all are expected to enter waged work. For those with few qualifications or 
work experience, self-employment appears to offer a flexible route to an income. This poses a significant challenge for the women involved. As a consequence of their restricted access to labour-market opportunities, they possess significantly less of the human and social capital recognised as being essential to business ownership. Despite this, recognising the importance of self-employment as an income generator for what they term 'disadvantaged women', WBCs in the US have developed programmes specifically targeted at this group. Essentially, the most economically and socially disadvantaged, possessing few of the social and human capital resources required to succeed in business ownership, have been identified as targets for encouraging female levels of self-employment. Considered alongside figures which demonstrate that, while the UK female self-employment rate has increased over time but the female share of self-employment has remained constant at around $26 \%$ for more than fifteen years, this suggests that reasons accounting for the fragile nature of self employed women in the UK should be investigated and used to inform policy in this area. Support for this is offered by research which questions the economic and social viability of targeting those in possession of few of the resources needed to succeed in business ownership (Bond and Kersey, 2002; Kellard and Middleton, 1998) and evidence of the underperformance of woman-owned businesses (Marlow and Carter, 2006).

To conclude, the analyses presented suggest that UK policy should be cautious of identifying the US as the benchmark for female participation in business ownership. UK policy should recognise the markedly different socioeconomic history of the UK and the implications which a less extreme approach to the liberal provision of welfare support has for women's business ownership. While drawing from good practice examples from other countries, including but not restricted to the US, policy in this area should reflect the UK's national context and socioeconomic trends. In particular, shifting concentration from initiatives designed to boost female participation in business ownership to those concerned with improving the sustainability of women-owned firms is likely to generate greater economic and social benefits whilst avoiding problematic displacement effects. This approach requires a longer-term view, sensitive to the manner in which self-employment reflects employment structures and opportunities. Hence, the greater penetration of women into higher-order employment will be followed by changes in selfemployment. This trend has already been identified in professions such as accountancy, although vertical segregation still persists (Marlow and Carter, 2004). In essence, the message to policy makers is to focus on supporting quality and sustainability. Encouraging more women to enter self-employment without considering the implications of displacement and crowding in poorer performing segments of the service sector is likely to contribute to even higher rates of closure and exit than those already evident amongst women business owners. This will not achieve the much-vaunted contribution to the British economy nor will it offer women bright entrepreneurial futures.

Acknowledgements. The authors would like to thank Julian Frankish and two anonymous referees for their comments on an earlier draft. The authors are also grateful for comments received on earlier drafts of this paper from participants at the British Academy of Management conference 2007 and Institute for Small Business and Entrepreneurship conference 2007.

\section{References}

Acs Z J (Ed.), 1999 Are Small Firms Important? Their Role and Impact (Kluwer, Norwell, MA)

Ahl H, 2002 The Making of the Female Entrepreneur: A Discourse Analysis of Research Texts on Women's Entrepreneurship PhD Dissertation Series No.15, Jönköping International Business School, PO Box 1026, SE-551 11, Jönköping

Ahl H, 2006, "Why research on women entrepreneurs needs new directions" Entrepreneurship Theory and Practice $30595-622$

Audretsch D, 1999, "Small firms and efficiency", in Are Small Firms Important? Their Role and Impact Ed. Z J Acs (Kluwer, Norwell, MA) pp $21-38$ 
Baines S, Wheelock J, Gelder U, 2003 Riding the Rollercoaster: Family Life and Self-employment (Polity Press, Cambridge)

Belle A, La Valle I, 2003 Combining Self-employment and Family Life (Polity Press, Cambridge)

Bem S, 1993 The Lens of Gender (Yale University Press, New Haven, CT)

Birley S, 1989, "Female entrepreneurs: are they really any different?" Journal of Small Business Management 27 7-31

Bond M, Kersey D, 2002, "Expanding childminding provision in areas of deprivation" Local Economy $17303-312$

Boston T (Ed.), 1996 A Different Vision: Race and Public Policy. Volume 2. African American Economic Thought (Routledge, London)

Boushey H, Gundersen B, Brocht C, Bernstein J, 2001, "Hardships in America: the real story of working families", Economic Policy Institute, 1333 H Street, NW, Suite 300, East Tower, Washington, DC

Bradley H, Erickson M, Stephenson C, Williams S (Eds), 2000 Myths at Work (Polity Press, Cambridge)

Brooksbank D, 2000, "Self-employment and small firms", in Enterprise and Small Business: Principles, Practice and Policy Eds S Carter, D Jones-Evans (FT Prentice Hall, Harlow, Essex) pp $7-31$

Brush C G, Hisrich R D, 1999, "Women-owned businesses: why do they matter", in Are Small Firms Important? Their Role and Impact Ed. Z J Acs (Kluwer, Norwell, MA) pp 111 - 127

Brush C, Carter N, Gatewood E J, Greene P, Hart M, 2006a Women and Entrepreneurship: Contemporary Classics (Edward Elgar, Cheltenham, Glos)

Brush C, Carter N, Gatewood E J, Greene P, Hart M, 2006b Growth Oriented Women Entrepreneurs and Their Businesses (Edward Elgar, Cheltenham, Glos)

Caizza A, Shaw A, Werschkul M, 2004, "The status of women in the United States", Institute for Women's Policy Research, 1707 L Street, NW, Suite 750, Washington, DC 20036

Carter S, 1993, "Female business ownership: current research and possibilities for the future", in Women in Business: Perspectives on Women Entrepreneurs Eds S Allen, C Truman (Routledge, London) pp $148-160$

Carter S, Bennett D, 2006, "Gender and entrepreneurship", in Enterprise and Small Business: Principles, Practice and Policy Eds S Carter, D Jones-Evans (FT Prentice Hall, Harlow, Essex) pp $176-191$

Carter S, Shaw E, 2006, "Women's business ownership: recent research and policy developments", report, to the Small Business Service, London, http://www.berr.gov.uk/files/file38330.pdf

Carter S, Anderson S, Shaw E, 2001, "Women's business ownership: a review of the academic, popular and internet literature", report to the Small Business Service, London, http://www.berr.gov.uk/files/file38362.pdf

Charles M, 2003, "Deciphering sex segregation: vertical and horizontal inequalities in ten national labour markets" Acta Sociologica 46267 - 287

Colli A, Rose M B, 2003, "Family firms in comparative perspective", in Business History Around the World Eds G Jones, F Amoretti (Cambridge University Press, Cambridge) pp 168-177

Colli A, Fernandez P P, Rose M B, 2003, "National determinants of family firm development? Family firms in Britain, Spain, and Italy in the nineteenth and twentieth centuries" Enterprise and Society $428-64$

Collins H, Moore M G, 1964 Enterprising Man (Michigan State University Press, East Lansing, MI)

Cranny-Francis A, Waring W, Stavropoulos K J, 2003 Gender Studies: Terms and Debates (Palgrave Macmillan, Basingstoke, Hants)

Crompton R, Lyonette C, 2006, "Some issues in cross-national comparative research methods: a comparison of attitudes to promotion, and women's employment, in Britain and Portugal" Work, Employment and Society $20403-414$

CWBR, 2004, "Capturing the impact: women-owned businesses in the United States", Center for Women's Business Research, 1411 K Street, NW, Suite 1350, Washington, DC 20005

CWBR, 2005, "Top facts about women-owned businesses", Center for Women's Business Research, 1411 K Street, NW, Suite 1350, Washington, DC 20005

Daly M, Rake K, 2003 Gender and The Welfare State: Care, Work and Welfare in Europe and the USA (Blackwell, Oxford)

de Beauvoir S, 1972 The Second Sex translation by H M Pashley (Penguin, Harmondsworth, Middx)

Epsing-Anderson G, 1999 Social Foundations of Post-industrial Economies (Oxford University Press, Oxford) 
Hakim C, 1979, “Occupational segregation by sex”, RP 9, Department of Employment, London, available from http://www.delni.gov.uk/index/statistics/research

Hakim C, 1989, "Identifying fast growth small firms" Employment Gazette (January) 29-41

Hamilton E, 2006, "Whose story is it anyway? Narrative accounts of the role of women in founding and establishing family businesses" International Small Business Journal 24(3) 253 - 271

Hipple S, 2004, "Self-employment in the United States: an update" Monthly Labor Review (July) $13-23$

Holmquist E, Sundin C, 1989, “'The growth of women's entrepreneurship-push or pull factors?”, paper presented to the European Institute for Advanced Studies in Management Conference on Small Business, University of Durham Business School, available from http://www.EIASM.be

IWPR, 2003, "Single mothers and their children suffered most last year with persistently high poverty", press release, 26 September, Institute for Women's Policy Research, Washington, DC, http://www.iwpr.org/pdf/PovertyNumbers.pdf

Jacobsen J P, 1998 The Economics of Gender 2nd edition (Blackwell, Oxford)

Jurik N, 2005 Bootstrap Dreams (Cornell University Press, Ithaca, NY)

Kellard K, Middleton S, 1998, "Helping unemployed people into self-employment", RP 46, Department for Education and Employment, London, available from http://www.delni.gov.uk/ index/statistics/research

Labour Force Survey, 1992, "Labour force survey quarterly survey", April, Office for National Statistics, 1 Drummond Gate, London SW1V 2QQ

Labour Force Survey, 2005/06, "Labour force survey quarterly survey", April, Office for National Statistics, 1 Drummond Gate, London SW1V 2QQ

Lindsay C, Macaulay C, 2004, "Growth in self-employment in the UK" Labour Market Trends 399 -404, http://www.statistics.gov.uk/articles/labour_market_trends/Growth_article.pdf

Lister R, 2003 Citizenship: Feminist Perspectives 2nd edition (Palgrave, London)

Marlow S, 1997, "Self employed women - do they mean business" Entrepreneurship and Regional Development $9199-210$

Marlow S, 2002, "Self-employed women: a part of or apart from feminist theory?" International Journal of Entrepreneurship and Innovation 283 -91

Marlow S, Carter S, 2004, "Accounting for change: professional status, gender disadvantage and self-employment" Women in Management Review 195 - 16

Marlow S Carter S, 2006, "If you don't ask you don't get! Women, self employment and finance", paper presented at the Warwick Business School Small Firms Finance Conference, May, http://www2.warwick.ac.uk/fac/soc/wbs/conf/int-sme-finance/programme/13_-_marlow.pdf

Marlow S, Watson E, Westall A, 2003, "Who benefits?", New Economics Foundation, London

Mead M, 1949 Male and Female (Morrow Quill, New York)

Minitti M, Arenius P, Langowitz N, 2005, "Global entrepreneurship monitor 2004 report on women and entrepreneurship", Babson College, Babson Park, MA

Mirchandani K, 1999, "Feminist insight on gendered work: new directions in research on women and entrepreneurship" Gender, Work and Organisation $6224-236$

Mirchandani K, 2005, "Women's entrepreneurship: exploring new avenues", in International Handbook of Women and Small Business Entrepreneurship Eds S Fielden, M Davidson (Edward Elgar, Cheltenham, Glos) pp $202-220$

NWBC, 2004, "Women business owners and their enterprises", National Women's Business Council, 409 Third Street, SW, Suite 210, Washington, DC 20024

Oakley A, 1973 Sex, Gender and Society (Temple Smith, London)

O'Connor J S, Orloff A S, Shaver S, 1999 States, Markets, Families: Gender, Liberalism and Social Policy in Australia, Canada, Great Britain and the United States (Cambridge University Press, Cambridge)

OECD, 2003 Women's Entrepreneurship: Issues and Policies Working Party on Small and Mediumsized Enterprises and Entrepreneurship (OECD, Paris)

OECD, 2005 OECD Factbook 2005: Economic, Environmental and Social Statistics (OECD, Paris)

Ogbor J O, 2000, "Mythicizing and reification in entrepreneurial discourse: ideology critique of entrepreneurial studies" Journal of Management Studies 35 605-635

O’Reilly J, 2006, "Framing comparisons: gendering perspectives on cross-national comparative research on work and welfare" Work, Employment and Society 20731 - 750

Orloff AS, 2003, "Markets not states? The weakness of state social provision for breadwinning men in the U.S.", in Families of a New World Eds L Haney, L Pollard (Routledge, New York) pp 217-245

Parker S, 2004 The Economics of Self-employment and Entrepreneurship (Cambridge University Press, Cambridge) 
Prowess Profile 2004 issue 2 (Spring), http://www.prowess.org.uk/pdfs/profile2.pdf

Prowess Profile 2006 (Summer/Autumn) issue 6, http://www.prowess.org.uk/about/documents/ Prowessprofile6.pdf

Rai S M, 2003, Mainstreaming Gender: Democratizing the State? Institutional Mechanisms for the Advancement of Women (Manchester University Press, Manchester)

Rosa P, Carter S, Hamilton D, 1996, "Gender as a determinant of small business performance: insights from a British study" Small Business Economics 8463 - 478

Rouse J, 2005, "Pregnancy and maternity in self-employment: individualised social reproduction?", paper presented at the 28th Institute for Small Business Entrepreneurship National Conference, Blackpool, November, available from http://www.Isbe.org.uk

Rouse J, Kitching J, 2006, "Do enterprise support programmes leave women holding the baby?" Environment and Planning C: Government and Policy 24 - 19

SBA, 2006, "Women in business: a demographic review of women's business ownership", Small Business Administration, available at http://www.sba.gov/advo/

Scase R, 1995, "Employment relations in small firms", in Industrial Relations: Theory and Practice in Britain Ed. P Edwards (Blackwell, Oxford) pp $470-489$

Scase R, 2000, "The enterprise culture: the socio-economic context of small firms", in Enterprise and Small Business: Principles, Practice and Policy Eds S Carter, D Jones-Evans (FT Prentice Hall, Harlow, Essex) pp 32-47

Schreier J, 1973 The Female Entrepreneur: A Pilot Study (Center for Venture Management, Milwaukee, WI)

Schwartz E B, 1976, "Entrepreneurship: a new female frontier" Journal of Contemporary Business (Winter) $47-76$

Segal L, 1989 Is the Future Female? Troubled Thoughts on Contemporary Feminism (Virago, London)

Shakeshaft C, Nowell I, 1984, "Research on themes, concepts and models of organisational behaviour: the influence of gender"Issues in Education 2 186-203

Skrentny J D (Ed.), 2001 Color Lines: Affirmative Action, Immigration, and Civil Rights Options for America (University of Chicago Press, Chicago, IL)

Small Business Service, 2003, “A strategic framework for women's enterprise, Small Business Service, London, http://www.prowess.org.uk/pdfs/strategic\%20framework.pdf

Small Business Service, 2006, "Annual survey of small businesses: UK 2005”, http://www.berr.gov.uk/ files/file38247.pdf

Thomas S, 1997, "Women, welfare, reform and the presentation of a myth" The Social Science Journal $34352-368$

US Bureau of Labor Statistics, 2005, "Unincorporated self-employed persons in nonagricultural industries by sex, 1976-2002 annual averages", http://www.bls.gov/cps/wlf.table32.pdf

US Census Bureau, 2002, "Historical income tables - full time, year round workers by median income and sex: 1955 to 2001", available at http://www.census.gov

US House of Representatives, 1964 Civil Rights Act H.R.7152 88th Congress

US House of Representatives, 1988 Women's Business Ownership Act H.R.5050 100th Congress

US House of Representatives, 1996 Personal Responsibility and Work Opportunity Reconciliation Act H.R.3734 104th Congress

Watson J, Robinson S, 2003, "Adjusting for risk in comparing the performance of male and female controlled SMEs" Journal of Business Venturing 18773 - 788

West C, Zimmerman D, 1987, "Doing gender" Gender and Society 1(1) 125 - 152

Wilson L, Whittam G, Deakins D, 2004, "Women's enterprise: a critical examination of national policies" Environment and Planning C: Government and Policy $22799-815$

Wolfe R, 2006, "How welfare reform changed America" USA Today 18 July, page 26 
Conditions of use. This article may be downloaded from the E\&P website for personal research by members of subscribing organisations. This PDF may not be placed on any website (or other online distribution system) without permission of the publisher. 